\title{
UJI EFEKTIVITAS ANTIBAKTERI EKSTRAK ETANOL DAN EKSTRAK AIR KELOPAK BUNGA ROSELLA (Hibiscus sabdariffa L) TERHADAP BAKTERI Streptococcus pneumoniae.
}

[THE EFFECTIVENESS TEST OF ANTIBACTERY OF ROSELLA SHEATH (Hibiscus sabdariffa L) ETHANOL EXTRACT AND WATER EXTRACT AGAINST Streptococcus pneumoniae]

\author{
Oom Komala ${ }^{1}$, Reni Rosyanti ${ }^{2}$, Muztabadihardja ${ }^{3}$ \\ ${ }^{1}$ Program Studi Biologi, ${ }^{2 \& 3}$ Program Studi Farmasi \\ FMIPA Universitas Pakuan \\ Jln. Pakuan PO BOX 452, Telp./Fax. (0251)8375547 Bogor \\ e-mail: komalaoom20@yahoo.co.id, Hp.081311405900
}

\begin{abstract}
ABSTRAK
Penelitian efektivitas antibakteri ekstrak etanol dan ekstrak air kelopak bunga rosella terhadap Streptococcus pneumoniae telah dilakukan menggunakan metode difusi cakram dan dilusi secara invitro. Larutan induk ekstrak etanol dan ekstrak air rosella 70g/100 ml diencerkan dengan konsentrasi 10\%, 30\%, 50\% dan70\% untuk metode difusi cakram dengan kontrol positif ampisilin $10 \mathrm{IU}$, dan ekstrak etanol diencerkan dengan konsentrasi $0,1 \%, 0,25 \%, 0,5 \%, 1 \%$, dan $2 \%$ untuk metode dilusi terhadap S.pneumoniae. Hasil penelitian menunjukkan bahwa ekstrak etanol dan ekstrak air rosella dapat menghambat pertumbuhan bakteri S.pneumoniae diketahui dari zona hambat yang terbentuk. Konsentrasi $70 \%$ pada metode difusi ekstrak etanol dan ekstrak air rosella membentuk diameter zona hambat paling luas rata-rata $25,6 \mathrm{~mm}$ untuk ekstrak etanol dan $24,3 \mathrm{~mm}$ untuk ekstrak air rosella. Hasil konsentrasi hambat minimum dari ekstrak etanol rosella yang paling efektif adalah konsentrasi 1\%. Hasil pengujian fitokimia diketahui bahwa ekstrak etanol dan ekstrak air rosella mengandung saponin, tanin, dan flavonoid.
\end{abstract}

Kata kunci : Kelopak Bunga Rosella (Hibiscus sabdariffa L), S.pneumoniae, antibakteri, ekstrak etanol, ekstrak air

\section{ABSTRACT}

The in vitro study of antibacterial effectiveness of Rosella sheath (Hibiscus sabdariffa L) ethanol extract and water extract on Streptococcus pneumoniae was conducted by diffusion and dilution method. Basic solution amounting to $70 \mathrm{~g} / 100 \mathrm{ml}$ of the extract was diluted into $10 \%, 30 \%, 50 \%$ and $70 \%$ for diffusion test with positive control ampicillin $10 \mathrm{IU}$, and $0,1 \%, 0,25 \%, 0,5 \%, 1 \%$, and $2 \%$ ethanol extract for dilution test on S.pneumoniae. The results showed that the ethanol extract and water extractcould delay of bacterium growth. Agar diffusion test (disk diffusion) was observed by diameter of barregion around the disk. At concentration $70 \%$ among extract ethanoland water extractmadebar zone wide the best, the diameter mean was estimated $25.6 \mathrm{~mm}$ for ethanol extract, and $24.3 \mathrm{mmfor}$ water extract on S.pneumoniae. In dilution test, the result showed Minimum Inhibitory Concentration (MIC) of the extract was $1 \%$ on S.pneumoniae. The result of phytochemicals test is known that ethanol extract and water extract of rosella contains of saponin, tanin, and flavonoid. 
Key Words : Rosella sheath(Hibiscus sabdariffa L), S. pneumoniae, Antibactery, ethanol extract, water extract

\section{PENDAHULUAN}

Salah satu tumbuhan obat yang saat ini sangat populer dan banyak digunakan oleh masyarakat untuk mengobati berbagai macam penyakit adalah bunga rosella (Hibiscus sabdariffa L). Tanaman rosella adalah sejenis perdu yang mudah ditanam. Rosella memiliki khasiat sebagai digestif (melancarkan pencernaan), antikanker, antihipertensi, antidiabetes, antiplasmodik (antikejang), antibakterial, anthelmintik (anticacing), memperlambat pertumbuhan jamur atau parasit penyebab demam tinggi, sebagai antioksidan karena tanaman ini mengandung senyawa flavonoid khususnya jenis antosianin serta betakaroten, mematikan Mycobacterium tuberculosis penyebab penyakit TBC (Mardiah dkk, 2009). Tetapi khasiat untuk mengatasi saluran pernafasan bagian atas belum banyak.

Saluran pernafasan atas adalah gerbang utama, tempat bakteri memasuki tubuh. Penyakit yang muncul melalui pernafasan umumnya adalah influenza, pneumonia, tuberkulosis dan cacar air (Alcamo, 1991).Obat-obat antibakteri sintetik secara komersil telah dikenal dan diandalkan dalam menanggulangi penyakit, diantaranya ampisilin. Tetapi obat sintetik menimbulkan efek samping yang serius dan perlu pengawasan dokter. Untuk mengetahui khasiat rosella sebagai obat untuk saluran pernafasan, maka dilakukan penelitian mengenai kemampuan ekstrak etanol dan ekstrak air rosella sebagai antibakteri terhadap bakteri S. pneumonia salah satu bakteri penyebab penyakit pada saluran pernafasan.Tujuan dari penelitian adalah untuk mengetahui aktivitas antibakteri ekstrak etanol dan ekstrak air kelopak bunga rosella dalam menghambat bakteri $S$. pneumoniae. Untuk mengetahui konsentrasi hambat minimum ekstrak etanol dan ekstrak air kelopak bunga rosella terhadap $S$. pneumoniae, serta untuk mengetahui kandungan fitokimia

saponin, tanin, dan flavonoid secara kualitatif kelopak bunga rosella.

\section{BAHAN}

Bahan yang digunakan meliputi kelopak bunga rosella (Hibiscus sabdariffa L) (Gambar 1), bakteri uji Streptococcus pneumoniae, aquadest, etanol 70\%, ampisilin (antibiotik pembanding), $\mathrm{H}_{2} \mathrm{SO}_{4}$, etanol 95\%, kloroform, $\mathrm{NaCl}$ fisiologis, serbuk magnesium, $\mathrm{HCl}$ pekat, amil alkohol, $\mathrm{HCl} 37 \%, \mathrm{FeCl}_{3}$ 1\%, media agar darah dan kertas cakram berdiameter 6 $\mathrm{mm}$.

\section{METODE}

\section{Penetapan Kadar Air , Kadar Abu Dan Kadar Senyawa}

Kelopak bunga rosella (Gambar 1) yang telah kering dihaluskan dengan cara digrinder sampai menjadi simplisia serbuk dan diayak dengan mesh 30. Karakterisasi serbuk rosella dilakukan terhadap kadar air melalui metode gravimetri sampai bobot tetap (Depkes RI, 1997), dan kadar abu, melalui pemijaran sampai bobot tetap (Depkes RI, 1997). Kadar abu yang tidak larut dalam asam diketahui melalui pendidihan kadar abu yang sudah diketahui dengan $25 \mathrm{ml}$ asam sulfat encer selama 5 menit, dikumpulkan bagian yang tidak larut dalam asam, disaring melalui krus kaca masir atau kertas saring bebas abu, dicuci dengan air panas, dipijarkan hingga bobot tetap, ditimbang (Depkes RI, 1997). Kadar abu yang larut dalam air ditentukan melalui pendidihan kadar abu yang sudah diketahui dengan $25 \mathrm{ml}$ air selama 5 menit. Dikumpulkan bagian yang tidak larut, disaring melalui krus kaca masir atau kertas saring bebas abu, dicuci dengan air panas dan dipijarkan selama 15 menit pada suhu $450^{\circ} \mathrm{C}$, hingga bobot tetap. Kadar senyawa yang larut dalam air ditentukan melalui maserasi 5 g ekstrak 
dengan $100 \mathrm{ml}$ air kloroform selama 24 jam menggunakan labu bersumbat sambil berkali-kali dikocok selama 6 jam pertama kemudian dibiarkan selama 18 jam. Disaring, diuapkan dengan $20 \mathrm{ml}$ filtrat hingga kering dalam cawan. Residu dipanaskan pada suhu $105^{\circ} \mathrm{C}$ hingga bobot tetap. Senyawa yang larut dalam asam diketahui melalui maserasi $5 \mathrm{~g}$ ekstrak dengan $100 \mathrm{ml}$ etanol (95\%) selama 24 jam, menggunakan labu bersumbat sambil berkali-kali dikocok selama 6 jam pertama dan kemudian dibiarkan selama 18 jam. Saring cepat untuk menghindarkan penguapan etanol, kemudian uapkan $20 \mathrm{ml}$ filtrat hingga kering dalam cawan, residu dipanaskan pada suhu $105^{\circ} \mathrm{C}$ hingga bobot tetap (Depkes RI, 1997).

\section{Pembuatan Ekstrak Etanol Dan Ekstrak Air}

Ekstrak rosella dilakukan dengan metode maserasi dan infus (Depkes RI, 1997). Metode maserasi yaitu dengan cara merendam $600 \mathrm{~g}$ serbuk dalam $4500 \mathrm{ml}$ etanol $70 \%$ selama 3 hari. Cairan jernih disaring, ampasnya ditambah lagi $1500 \mathrm{ml}$ etanol $70 \%$ direndam selama 2 hari. Cairan jernih diperlakukan sama seperti pertama, lalu keduanya disatukan. Cairan tersebut dikeringkan dengan vaccum rotavapor pada suhu $50^{\circ} \mathrm{C}$. Sedangkan pembuatan infus dilakukan dengan melarutkan $200 \mathrm{~g}$ serbuk kelopak bunga rosella dengan 1800 $\mathrm{ml}$ aquabidest. Campuran tersebut dipanaskan pada suhu $90^{\circ} \mathrm{C}$ selama 15 menit sambil diaduk. Setelah dingin cairan disaring dan dikentalkan dengan vaccum rotavapor. Ekstrak yang diperoleh selanjutnya diuji secara kualitatif kandungan senyawa flavonoid (Markham, 1998), tanin (dengan pereaksi $\mathrm{FeCl}_{3}$ ), dan saponin (dengan pereaksi $\mathrm{HCl} 2 \mathrm{~N}$ ) (Harbone, 1987).

\section{Pengujian Efektivitas Ekstrak Etanol Dan Ekstrak Air}

Bakteri yang sudah diencerkan konsentrasi $10^{6} / \mathrm{ml}$. dituangkan sebanyak
0,2 $\mathrm{ml}$ kedalam $15 \mathrm{ml}$ media agar darah hangat suhu $45^{\circ} \mathrm{C}$ secara aseptis. Setelah homogen kemudian kertas cakram yang mengandung ekstrak etanol dan ekstrak air rosella dari larutan induk $70 \mathrm{~g} / 100 \mathrm{ml}$ dan telah diencerkan dengan konsentrasi $10 \%, 30 \%, 50 \%$ dan $70 \%$, kontrol positif ampisilin $10 \mathrm{IU}$, dan kontrol negatif aquabidest di tempelkan di permukaan media agar dalam cawan petri (Sunatmo, 2007). Cawan petri tersebut diinkubasi selama 24 jam pada suhu $37^{0} \mathrm{C}$. Daerah bening disekitar kertas cakram ekstrak rosella dan ampisilin diukur. Pengujian dilakukan sebanyak 3 kali pengulangan.

\section{Penentuan Konsentrasi Hambat Minimum \\ Penentuan Konsentrasi Hambat} Minimum (KHM) dilakukan menggunakan metode dilusi cair. Larutan uji dibuat dengan mengencerkan larutan induk $70 \mathrm{~g} / 100 \mathrm{ml}$ secara serial dengan konsentrasi $0,1 \%, 0,25 \%, 0,5 \%, 1 \%, 2 \%$. Setiap konsentrasi ekstrak sebanyak $1 \mathrm{ml}$ masing-masing dituangkan ke dalam tabung reaksi steril bersamaan dengan 1 $\mathrm{ml}$ larutan suspensi bakteri yang diencerkan $10^{-6}$ kemudian tambahkan media BHI (Brain Heart Infusion) broth sebanyak $5 \mathrm{ml}$. Inkubasi pada suhu $37^{\circ} \mathrm{C}$. KHM ditentukan pada tabung reaksi konsentrasi ekstrak terendah yang tidak ditumbuhi bakteri (Prescott et al, 1993). Pengujian dilakukan dengan 3 kali ulangan. Untuk membandingkan pengaruh ekstrak kelopak bunga rosella dengan kontrol positif ampisilin 10 IU terhadap $S$. pneumoniae, data diameter daerah hambat dianalisis menggunakan Rancangan Acak Lengkap (RAL) sederhana dan diuji lanjut menggunakan Uji Duncan, serta Rancangan Acak Lengkap (RAL) Faktorial pola $2 \times 4 \times 3$ untuk membandingkan kualitas ekstrak etanol dan ekstrak air rosella. Data yang diperoleh dianalisis dengan menggunakan SPSS 17. 


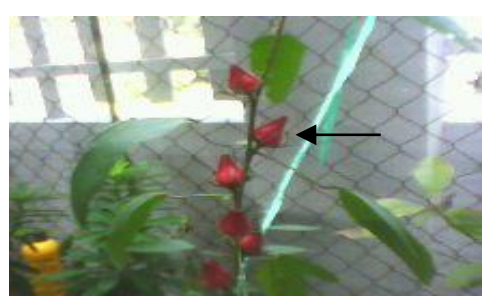

HASIL

Gambar 1. Bunga Rosella (Hibiscus sabdariffa L)

\section{Hasil Uji Farmakognosi Kelopak Bunga Rosella}

Data hasil pengujian parameter farmakognosi serbuk dan ekstrak roselladapat dilihat pada Tabel 1.

Tabel 1. Hasil Farmakognosi Serbuk dan Ekstrak Rosella

\begin{tabular}{|l|c|c|c|}
\hline \multicolumn{1}{|c|}{ Pemeriksaan } & $\begin{array}{c}\text { Ekstrak Etanol } \\
\text { Rosella (\%) }\end{array}$ & $\begin{array}{c}\text { Ekstrak Air Rosella } \\
(\%)\end{array}$ & $\begin{array}{c}\text { Serbuk Rosella } \\
(\%)\end{array}$ \\
\hline kadar air & 7,80 & 2,15 & 13,02 \\
\hline kadar abu & 5,11 & 7,19 & 5,92 \\
\hline kadar abu yang tidak larut asam & 2,79 & 5,2 & - \\
\hline kadar abu yang larut air & 24,5 & 49,9 & - \\
\hline kadar senyawa yang larut air & 72,10 & 64,05 & - \\
\hline kadar senyawa yang larut asam & 74,22 & 37,72 & - \\
\hline
\end{tabular}

\section{Hasil Uji Fitokimia}

Berdasarkan hasil penelitian diketahui bahwa serbuk rosella berwarna merah muda, berasa asam dan berbau aromatis. Ekstrak etanol rosella berwarna hitam, berasa asam dan berbau aromatis. Ekstrak air rosella berwarna hitam

kemerahan, berasa asam dan berbau aromatis. Berdasarkan hasil pemeriksaan fitokimia pada ekstrak etanol dan ekstrak air rosella menunjukkan hasil yang sama, yaitu positif mengandung senyawa saponin, flavonoid dan tanin (Tabel 2).

Tabel 2. Hasil Uji Fitokimia Ekstrak Etanol dan Ekstrak Air Rosella

\begin{tabular}{|l|l|c|c|}
\hline Golongan senyawa & Hasil analisis & a) & b) \\
\hline Saponin & Busa stabil & + & + \\
\hline Flavonoid & Merah Jingga & + & + \\
\hline \multirow{3}{*}{ Tanin } & $+\mathrm{FeCl}_{3}=$ hijau kehitaman & + & + \\
\cline { 2 - 4 } & + gelatin = endapan putih & + & + \\
\hline
\end{tabular}

Keterangan : + = positif, a) Ekstrak etanol,b) Ekstrak air

Hasil Uji Efektivitas Antibakteri

Ekstrak Etanol dan Ekstrak AirRosella

Terhadap Streptococcus pneumoniae.

Berdasarkan hasil penelitian

(Gambar 2), bakteri S. pneumoniae yang ditumbuhkan pada media agar darah dan di uji terhadap ekstrak etanol kelopak bunga rosella, ampisilin dan aquadest, membentuk zona hambat setelah diinkubasi pada suhu $37^{\circ} \mathrm{C}$ selama 24 jam. Diameter daerah hambat ekstrak etanol rosella tercantum dalam Tabel 3.

Tabel 3. Hasil Uji Difusi Ekstrak Etanol Rosella

\begin{tabular}{|c|c|c|c|c|c|c|}
\hline Ulangan & \multicolumn{6}{|c|}{ Diameter Daerah Hambat (mm) } \\
\hline & $10 \%$ & $30 \%$ & $50 \%$ & $70 \%$ & K (-) & $\mathrm{K}(+)$ \\
\hline 1 & 14 & 19 & 24 & 27 & 0 & 18 \\
\hline 2 & 12 & 19 & 20 & 22 & 0 & 18 \\
\hline 3 & 16 & 22 & 24 & 28 & 0 & 20 \\
\hline Total & 42 & 60 & 68 & 77 & 0 & 56 \\
\hline Rata-rata & $14 \mathrm{a}$ & $20 \mathrm{ab}$ & $22,6 \mathrm{ac}$ & 25,6 ac & 0 & $18,7 \mathrm{a}$ \\
\hline
\end{tabular}




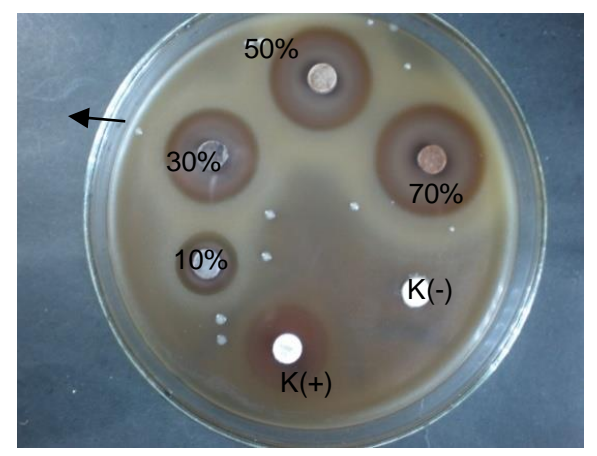

Gambar 2. Diameter Daerah Hambat Ekstrak Etanol Rosella. $\mathrm{K}+$ :ampisilin $10 \mathrm{IU}, \mathrm{K}-$ : aquabidest

Gambar 3 memperlihatkan zona hambat ekstrak air rosella. Pada konsentrasi $70 \%$ zona hambat paling luas dalam

$$
\text { menghambat pertumbuhan bakteri }
$$
S.pneumoniae(Tabel 4).

Tabel 4. Hasil Uji Difusi Ekstrak Air Rosella

\begin{tabular}{|c|c|c|c|c|c|c|}
\hline \multirow[t]{2}{*}{ Ulangan } & \multicolumn{6}{|c|}{ Diameter Daerah Hambat (mm) } \\
\hline & $10 \%$ & $30 \%$ & $50 \%$ & $70 \%$ & $\mathrm{~K}(-)$ & $\mathrm{K}(+)$ \\
\hline 1 & 17 & 22 & 23 & 25 & 0 & 18 \\
\hline 2 & 18 & 21 & 22 & 23 & 0 & 18 \\
\hline 3 & 16 & 20 & 21 & 25 & 0 & 20 \\
\hline Total & 51 & 63 & 66 & 73 & 0 & 56 \\
\hline Rata-rata & $17 \mathrm{a}$ & $21 \mathrm{ab}$ & $22 \mathrm{ac}$ & $24,3 \mathrm{ac}$ & 0 & $18,7 \mathrm{a}$ \\
\hline
\end{tabular}

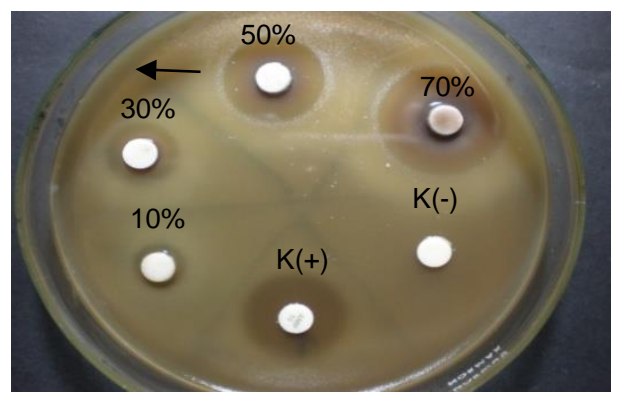

Gambar 3. Diameter Daerah Hambat Ekstrak Air Rosella. $\mathrm{K}+$ :ampisilin $10 \mathrm{IU}$, K- : aquabidest

Konsentrasi Hambat Minimum (KHM).

Berdasarkan hasil pengamatan ekstrak etanol dan air rosella pada difusi agar menunjukkan kualitas yang sama secara statistik, maka penentuan konsentrasi hambat minimum hanya dilakukan pada ekstrak etanol saja. Dari penelitian terhadap konsentrasi $0,1 \%$, $0,25 \%, \quad 0,5 \%, \quad 1 \%, \quad$ dan2\% ekstrak etanol,pada konsentrasi $1 \%$ menunjukkan konsentrasi hambat minimum dalam menghambat bakteri S. pneumoniae.

\section{PEMBAHASAN}

Penetapan kadar air simplisia rosella perlu dilakukan sebelum melakukan ekstraksi dengan tujuan untuk memberikan batasan minimal atau rentang besarnya kandungan air dalam suatu bahan.Karena air yang tersisa dalam simplisia pada kadar tertentu dapat menjadi media pertumbuhan kapang dan jasad renik (Depkes RI, 1997). Hasil penetapan kadar air serbuk rosella diperoleh sebesar 13,02\%. Hasil tersebut belum memenuhi standar kadar air 
simplisia yang diperbolehkan. Berarti serbuk rosella harus segera diproses. Sedangkan hasil penetapan kadar abu simplisia rosella diperoleh sebesar 5,92\%. Hasil tersebut memenuhi ketentuan kadar abu DepKes RI (1997).Nilai kadar abu simplisia memberikan gambaran kandungan senyawa anorganik (mineral internal dan eksternal) yang terkandung dalam simplisia, baik yang berasal dari tanaman secara alami maupun kontaminan selama proses pembuatan simplisia.

Penetapan kadar abu yang tidak larut asam tujuannya adalah untuk mengetahui kandungan silika, batu, debu, gumpalan tanah yang berada dalam sampel yang harus dibuang. Penetapankadar abu yang larut air dilakukan untuk mengetahui kandungan oksida-oksida yang larut dalam air. Hasil penelitian menunjukkan kandungan oksida yang larut dalam air, ekstrak etanol lebih besar dari ekstrak air rosella.Hasil penelitian juga menunjukkan kandungan oksida yang larut dalam asam, ekstrak etanol lebih besar dari ekstrak air rosella. Dengan demikian ekstrak etanol lebih baik dalam menarik oksida baik dalam pelarut air maupun dalam pelarut asam.

Penetapan kadar senyawa yang larut dalam air dan kadar senyawa yang larut dalam etanol bertujuan untukmemberikan gambaran awal jumlah kandungan senyawa yang dapat larut dalam air dan etanol (Depkes, RI 1997). Hasil yang diperoleh kandungan senyawa yang larut dalam air, ekstral etanol lebih besar dari ekstrak air rosella. Ekstrak etanol lebih baik dalam menarik senyawa yang terdapat pada rosella.

Terbentuknya zona hambat pada ekstrak etanol dan ekstrak air bunga rosella kemungkinan ada hubungannya dengan kandungan senyawa kimianya.. Berdasarkan hasil penelitian bunga rosella mengandung senyawa tanin, saponin dan flavonoid. Namun demikian ketiga senyawa tersebut perlu dilakukan pemurnian senyawa (isolasi) lanjutanuntuk diuji aktivitas antibakterinya terhadap $S$. pneumonia. Tanin terdapat dalam tumbuhan dapat bersifat sebagai antibakteri. Saponin juga dapat bersifat sebagai antibakteri. Mekanisme saponin merusak sel darah melalui interaksi antara bagian aktif dari senyawa saponin yaitu aglikon hidrofobik dengan lapisan lipid sehingga molekul saponin dapat memasuki membran (Wiryowidagdo, 2008). Peristiwa ini menyebabkan kebocoran pada dinding sel sehingga sel mengalami ketidakseimbangan ion dan mengalami lisis. Saponin diabsorpsi pada permukaan sel akan mengakibatkan terjadinya kerusakan dengan naiknya permeabilitas membran sel bakteri, sehingga bahan esensial yang dibutuhkan oleh bakteri untuk kelangsungan hidupnya akan hilang dalam hal ini akan menyebabkan kematian. Flavonoid secara sistemik bertindak sebagai imunostimulator yang dapat meningkatkan respon tubuh hospes terhadap parasit. Flavonoid yang bersifat lipofilik mungkin juga merusak membran mukosa, fenol sangat mudah diserap melalui jaringan. Secara sistemik, fenol merangsang susunan syaraf pusat dan menyebabkan kelumpuhan karena kejang otot. Flavonoid merupakan senyawa polifenol yang bersifat polar. Senyawa ini dapat bekerja sebagai antibakteri karena dapat mendenaturasi dan mengkoagulasi protein sel bakteri sehingga sel bakteri mati (Wiryowidagdo, 2008).

Sifat ekstrak bunga rosella yang dapat menimbulkan efek daya hambat terhadap pertumbuhan mikroorganisme, karena senyawa komponen aktif yang terkandung di dalamnya. Berdasarkan analisis menggunakan rancangan acak lengkap (RAL), kemudian dianalisis lanjut menggunakan Uji Duncan dan LSR, menunjukkan semakin tinggi konsentrasi ekstrak etanol rosella maka efektivitas antibakterinya pun semakin kuat (Tabel 3). Data Tabel 3 dan Tabel 4 di analisis menggunakan Rancangan Acak Lengkap (RAL) faktorial pola $2 \times 4 \times 3$ untuk mengetahui pengaruh kualitas dari ekstrak etanol dan ekstrak air rosella. Hasil 
analisis menunjukkan bahwa ekstrak etanol dan ekstrak air rosella mempunyai efektifitas yang sama dalam menghambat pertumbuhan bakteri Streptococcus pneumonia $(\mathrm{P}<0,05)$. Sedangkan besar konsentrasi pada ekstrak etanol dan air rosella mempunyai pengaruh yang berbeda dalam menghambat pertumbuhan bakteri S. pneumoniae. Pada konsentrasi $70 \%$ ekstrak etanol dan ekstrak air rosella mempunyai zona hambat paling luas dibandingkan dengan konsentrasi ekstrak yang lainnya. Konsentrasi hambat minimum dicapai pada ekstrak etanol dengan konsentrasi $1 \%$ dalam menghambat bakteri $S$. pneumoniae.

\section{KESIMPULAN}

Hasil uji fitokimia ekstrak etanol dan ekstrak air kelopak bunga rosella mengandung senyawa tanin, saponin dan flavonoid. Efektivitas kedua ekstrak sama baik dalam menghambat pertumbuhan bakteri Streptococcus pneumonia, semakin tinggi konsentrasi ekstrak maka semakin besar efektivitasnya. KHM dicapai pada konsentrasi $1 \%$ (dari larutan induk $70 \mathrm{~g} / 100 \mathrm{ml}$ ). Sebagai saran, penelitian berkelanjutan perlu dikembangkan seperti menguji senyawa tanin, saponin dan flavonoid ekstrak etanol dan ekstrak air bunga rosella langsung terhadap bakteri Streptococcus pneumonia menggunakan kromatografi, menguji aktifitasnya terhadap Mycobacterium tubercolosis, menguji senyawa aktif lain seperti alkaloid dan steroid/terpenoid, sifat-sifat kimianya, sampai suatu produk herbal untuk mengobati saluran pernapasan.

\section{DAFTAR PUSTAKA}

Alcamo IE. 1991. Fundamental of Microbiology. The Benjamin/Cummings Publishing Company, Inc. Canada.222.

DepKes RI. 1985. Cara Pembuatan Simpisia.Direktorat Jendral Pengawas Obat Dan Makanan.Jakarta.2-14.

Harbone JB. 1987. Metode Fitokimia. Edisi II. Diterjemahkan oleh Padmawinata. ITB. Bandung.21-27.

Mardiah, Sawarni, W Ashadi, dan A Rahayu. 2009. Budidaya dan pengolahan rosella simerah segudang manfaat. Agromedia Pustaka. Jakarta.23.

Markham KR. $1998 . \quad$ Cara Mengidentifikasi Flavonoid. Diterjemahkan Padmawinata, ITB. Bandung.8-14.

Prescott LM, JP Harley and DA.Klein. 1993. Microbiology. Wm.C. Brown Publishers, United State of America.328.

Sunatmo TI. 2007. Eksperimen Mikrobiologi dalam Laboratorium. Penerbit Ardy Agency, Jakarta.144. Wiryowidagdo S. 2008. Kimia dan Farmakologi Bahan Alam. Buku Kedokteran EGC.310. 